\title{
GRAMMATICAL TRANSPOSITION IN LITERARY TEXT
}

\section{Oksana Kuntso ${ }^{1}$}

\section{DOI: https://doi.org/10.30525/978-9934-588-52-5-11}

A great deal of attention in cognitive linguistic studies is devoted to language structures and their role in the literary text, especially, its imagery. The latter one is vastly provided by the grammatical metaphor, which is based on the phenomenon of grammatical transposition. It consists in the transposition (transfer) of the grammatical form of a certain type of grammatical connections to another, during which the redistribution of grammatical and lexical meanings and the creation of a new connotation, respectively, take place [1, p. 91]. The determining factor of this process is the source meaning, which affects the grammatical form [2, p. 17].

Traditionally, the following types of grammatical transpositions are distinguished [3, p. 91-92]: transposition of a certain grammatical form into a new syntactical distribution with the formation of contrast, as a consequence (historical present: a verb in the Present Indefinite form is used against the background of the Past Indefinite narration); transposition of grammatical and lexical meanings, simultaneously (the use of the plural form with a noun whose lexical denotative meaning is incompatible with plurality); transposition of a classifying grammatical meaning that unites occasionally incompatible forms (the use of a common noun as a proper one).

Thus, in N. Hawthorne's novel The Scarlet Letter, negative human traits of ruthlessness are capitalized and used with the definite article: "All that guilty sorrow, hidden from the world, whose great heart would have pitied and forgiven, to be revealed to him, the Pitiless, to him, the Unforgiving» [4, p. 118].

Often, in fiction, the images of the protagonists receive psychological and personal boundaries, defined by their names. The proper names of such characters as Chillingworth, Hester, Pearl and Dimmesdale are also formed by grammatical transposition. The antonomasia used by the author (the third type of grammatical transposition [1, p. 92]) leads to the image symbolizing certain features or qualities. That is, the proper names of the characters predetermine their function in the novel.

Hester Prynne's husband is hiding under the fictitious name CHILLINGWORTH. The root of the word «chill» (meaning cold or insensitive, indifferent to other people's worries and problems) in combination with the adjective «worth» integrate the quite antagonistic image - one that

\footnotetext{
${ }^{1}$ State Agrarian and Engineering University in Podillia, Ukraine
} 
causes cold or illness, as opposed to the traditional function of a doctor. The very word «cold» symbolically corresponds to the state of expectation or solitude, and the result of cooling the atmosphere is nothing but silence and dehumanization [5, p. 52].

The interpretation of the name of the novel protagonist, HESTER, is a bit more complicated. If we discard the suffix «er» from the word «hester», we get the archaic form of the verb «behest» - that is, to order, or dictate their rules, new laws. Due to this function of the main character, the new faith and worldview is created, which is realized in the text of the novel through the gradation of the symbolic meaning of the SCARLET LETTER.

PEARL, according to Cirlot [5, p. 251], symbolizes the «spirit in the dark» and its function is to represent the mystical centre of purification - such an elevation that is a modification of weakness or moral ugliness. That the PEARL is a «treasure of an oyster» [6, p. 151] makes it possible to assume that it is hidden, or symbolizes something that we find under vile or unpleasant conditions: «She had been offered to the world, these seven past years, as the living hieroglyphic, in which was revealed the secret they so darkly sought to hide, - all written in this symbol, - all plainly manifest» [4, p. 176].

Interesting, in terms of its symbolic function, is the image of Pearl's father the Puritan clergyman DIMMESDALE. From the very first pages of the novel, he is a true example and a representation of the religion of the time. However, it is not his faith-contemplation (which he, in fact, betrays) but the name, or rather its components «dim»(meaning gloomy, obscure) and «dale» (the valley) that becomes symbolic. The very combination of these two words symbolizes the delusion in which New England was, under the influence of Puritanism: «Then, what was he? - A substance? - Or the dimmest of all shadows? [4, p. 121]»; «I, your pastor, whom you so reverence and trust, I'm utterly a pollution and a lie [4, p.122]».

The imagery of a literary text is marked by a balance of individual and typical characteristics - images of characters, events, nature acquire authenticity and vitality due to specific, individual properties [7, p. 185-186]. The main characters are characterized as figures, in those episodes in which their temporal or spatial movement relative to the background is noticeable; the development of the novel also contributes to qualitative movement of figures, as far as, the main characters develop, acquiring new psychological characteristics [8, p. 16].

The main character (HESTER), thanks to her moral strength and will to reform, is actually purified of the views and beliefs of vague Puritanism (DIMMESDALE) and finds spiritual insight (PEARL). Such a change is realized due to and simultaneously with the transformation of the meaning of the image-symbol of the SCARLET LETTER. 
Involvement of such a method is not accidental. The revealed grammatical transposition reduces the functions of the main characters exclusively to the depiction of certain traits or moral qualities. At the mental level, they cease to be perceived by the reader as figures, but only create a background and a favourable environment for the development of a key image-symbol.

\section{References:}

1. Znamenskaya, T. A. (2004). Stilistika angliyskogo yazyka. Osnovy kursa [Stylistics of the English language. Course Basics]. Moscow: Editorial. (in Russian)

2. Panther, K-U. \& Thornburg, L. L. (2009). Introduction on figuration in grammar. Metonymy and Metaphor in Grammar (eds. K. Panther, L. L. Thornburg \& A. Barcelona). San Diego: John Benjamins, vol. 25, pp. 3-40.

3. Arutyunova, N. D. (1990). Obraz, metafora, simvol v kontekste zhizni i kul'tury [Image, metaphor, symbol under the life and culture context]. Res Philologica. Filologicheskie issledovaniya [Res Philologica. Philological research]. Moscow: Nauka, pp. 71-88.

4. Hawthorne, N. (1994). The Scarlet Letter. London: PENGUIN BOOKS.

5. Cirlot, J. E. (2001). A Dictionary of Symbols. $2^{\text {nd }}$ edition (translated from the Spanish by Jack Sage). London: Taylor \& Francis e-Library.

6. Ferber, M. (1999). A Dictionary of Literary Symbols. New York: Cambridge University Press.

7. Kukharenko, V. A. (2004). Interpretatsiia tekstu [Text interpretation]. Vinnytsia: Nova Knyha. (in Ukrainian)

8. Stockwell, P. (2005). Cognitive Poetics. An Introduction. London; New York: Taylor \& Francis e-Library.

\section{CORRESPONDENCE BETWEEN W. CHURCHILL AND F. ROOSEVELT: GENRE-STYLE DOMINANTS}

\section{Olga Semeniuk ${ }^{1}$}

\section{DOI: https://doi.org/10.30525/978-9934-588-52-5-12}

Recent studies in epistolography scrutinize the genre nature of writers' epistolary that has attracted the close attention of many scholars. Despite the fact that for the last decades the study of such a phenomenon in literature as the writer's epistolary has been giving a rise to controversy and divergent views of most scholars on the issues related to the specificity, genre nature,

\footnotetext{
${ }^{1}$ Educational \& Scientific Center of Language Training of the National Academy of the Security Service of Ukraine, Ukraine
} 